\begin{tabular}{|c|c|c|c|c|c|c|}
\hline \multirow{4}{*}{ Impact Factor: } & ISRA (India) & $=3.117$ & SIS (USA) & $=0.912$ & ICV (Poland) & $=6.630$ \\
\hline & ISI (Dubai, UAE & $=0.829$ & РИНЦ (Russia) & $=0.156$ & PIF (India) & $=1.940$ \\
\hline & GIF (Australia) & $=0.564$ & ESJI (KZ) & $=8.716$ & IBI (India) & $=4.260$ \\
\hline & JIF & $=1.500$ & SJIF (Morocco) & $=5.667$ & OAJI (USA) & $=0.350$ \\
\hline
\end{tabular}

\section{SOI: $1.1 /$ TAS $\quad$ DOI: $10.15863 /$ TAS \\ International Scientific Journal Theoretical \& Applied Science}

p-ISSN: 2308-4944 (print) e-ISSN: 2409-0085 (online)

Year: 2019 Issue: $07 \quad$ Volume: 75

Published: $30.07 .2019 \quad$ http://T-Science.org
QR - Issue

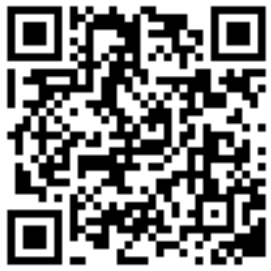

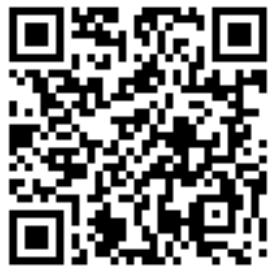

R.I. Nurimbetov

Tashkent Architecture and Civil Engineering Institute Prof. Scientific advisor

M.R. Khidirova

Tashkent State University of Economics

$\mathrm{PhD}$ researcher

\title{
MECHANISMS FOR IMPLEMENTING CORPORATE GOVERNANCE IN INDUSTRY DEVELOPMENT IN UZBEKISTAN
}

Abstract: In this paper work it is studied corporate governance system in case of industry section of Uzbekistan. In the period of transition and diversification of the national economy and after the new economic development reforms converting in clustering methods Uzbekistan considered one of the most effective implementation of the corporate policies. Labor division and specialization of the regions could have been innovated into modern development goals of export oriented policy of the government. Stockholders by local and international investors contribute their efforts by capital inflow and outflow within the country and outside the country. Particular attention was paid to the development of agricultural machinery sector, manufacturing process and service sector oriented new approaches have developed by firms and companies. In addition, few economic models are distributed under regional statistic data. Conclusion is represented with the international cooperation for effective economic growth.

Key words: corporate governance, industry, development, economic model, joint-stock companies.

Language: English

Citation: Nurimbetov, R. I., \& Khidirova, M. R. (2019). Mechanisms for implementing corporate governance in industry development in Uzbekistan. ISJ Theoretical \& Applied Science, 07 (75), 438-445.

Soi: http://s-o-i.org/1.1/TAS-07-75-71 Doi: crossef https://dx.doi.org/10.15863/TAS.2019.07.75.71

Classifiers: economic.

\section{Introduction}

From the years of independence, the development of the industry and its extensive network have radically changed. New industries have been found in the industry and their share in the GDP of the country has increased. Oil and gas, electronics, automotive, textile, raw materials processing and new agricultural machinery have become the priority industries. High-tech and value-added products are produced in these sectors. Such changes in the industry have led to rapid growth in the country. Corporate governance is a unique process not only in industrial production, but also in other sectors of the economy. From this point of view, the use of industrywide corporate governance is a good way to do so. There is practically no experience of corporate governance in the industry of Uzbekistan. Therefore, it is important to study the mechanism of its introduction into the industry and increase the efficiency of corporate production.

\section{Methods}

In this article authors used secondary source data analysis of quantitative methods with various source of data collection. And some statistical analysis of the government body.

\section{Literature review}

The notion of "corporate governance" is extensive, and many scientists have expressed it. For example, I. Khraborova argues that corporate governance, the management of organizational-legal regulation of this business, is an inter-agency internal structure of the company [1].

Karnaukov describes corporate governance as managing a certain set of synergies. S.A.Massyuktin describes corporate governance as a combination of 


\begin{tabular}{|c|c|c|c|c|c|c|}
\hline \multirow{4}{*}{ Impact Factor: } & ISRA (India) & $=3.117$ & SIS (USA) & $=0.912$ & ICV (Poland) & $=6.630$ \\
\hline & ISI (Dubai, UAE & $=0.829$ & РИНЦ (Russia) & $=0.156$ & PIF (India) & $=1.940$ \\
\hline & GIF (Australia) & $=0.564$ & ESJI (KZ) & $=8.716$ & IBI (India) & $=4.260$ \\
\hline & JIF & $=1.500$ & SJIF (Morocco) & $=5.667$ & OAJI (USA) & $=0.350$ \\
\hline
\end{tabular}

relationships between managers and owners of the enterprise to ensure the efficiency of the enterprise and protect the interests of owners and other participants [2]. Corporate Governance Concept, as expressed in S. Kukura's Conceptual Framework, includes the field of practical and scientific knowledge and the practice of organizing and coordinating largescale enterprise enterprises [3].

Other point to the concept of corporate governance as part of the corporate governance curriculum. Corporate Governance identifies a set of rules and culture that governs and controls a corporation that strives for the benefit of its stakeholders, such as people, customers and suppliers, in close proximity settlements [4].

According to Sh.Zaynutdinov and D.Rahimova, the economist from Uzbekistan, "Corporate Governance is a joint effort of interested parties to make profit [5].

Prof. M. Hamidulin explained the concept of " corporate governance "- it is the ownership of corporations, the strategic environment for more effective use of the product and the fair distribution of incomes derived from all of the corporate relationships, [6] definition "The corporate governance is a type of activity carried out to achieve business goals based on certain principles of governance, based on existing legal norms, irrespective of the form of ownership ..." is described [7].

Speaking about corporate governance, Professor B. Berkinov concluded that corporate governance is a system that is, first of all, a complex, rapidly changing mechanism that is interconnected by many interconnected entities, documents and a set of internal normative documents that constitute an internal mechanism for controlling the corporation by proprietors, managers and lenders [8].

$\mathrm{N}$. Rasulov explains the concept of corporate governance as follows: "It is a system that operates on the basis of goals, objectives and relationships inherent in corporate governance laws, mechanisms and principles."

Based on the above concepts of corporate governance, the author posed the following problem. Corporate governance is a day-to-day management system designed to increase profitability and efficiency of enterprises.

\section{Results}

The key objective of introducing a corporate governance-based management mechanism in industry is to ensure that businesses benefit from a high level of enterprise balance.

In order to introduce corporate governance in industrial enterprises, it is necessary to increase the responsibility of chairmen of the executive body, supervisory board and auditing committee members. In implementing corporate governance in industrial enterprises, priority should be given to legalnormative documents, regulations, guidelines and most importantly the Corporate Code.

All the existing industrial enterprises in Uzbekistan are joint-stock companies. Therefore, in the implementation of corporate governance all actions must be linked to the activities of the shareholders. In today's conditions, the protection of shareholders' rights is one of the main objectives of the company's development. Currently 603 joint-stock companies operate in the country, of which are the joint-stock companies in the industry. The development of joint-stock companies in the industry is given in the following Figure 1.

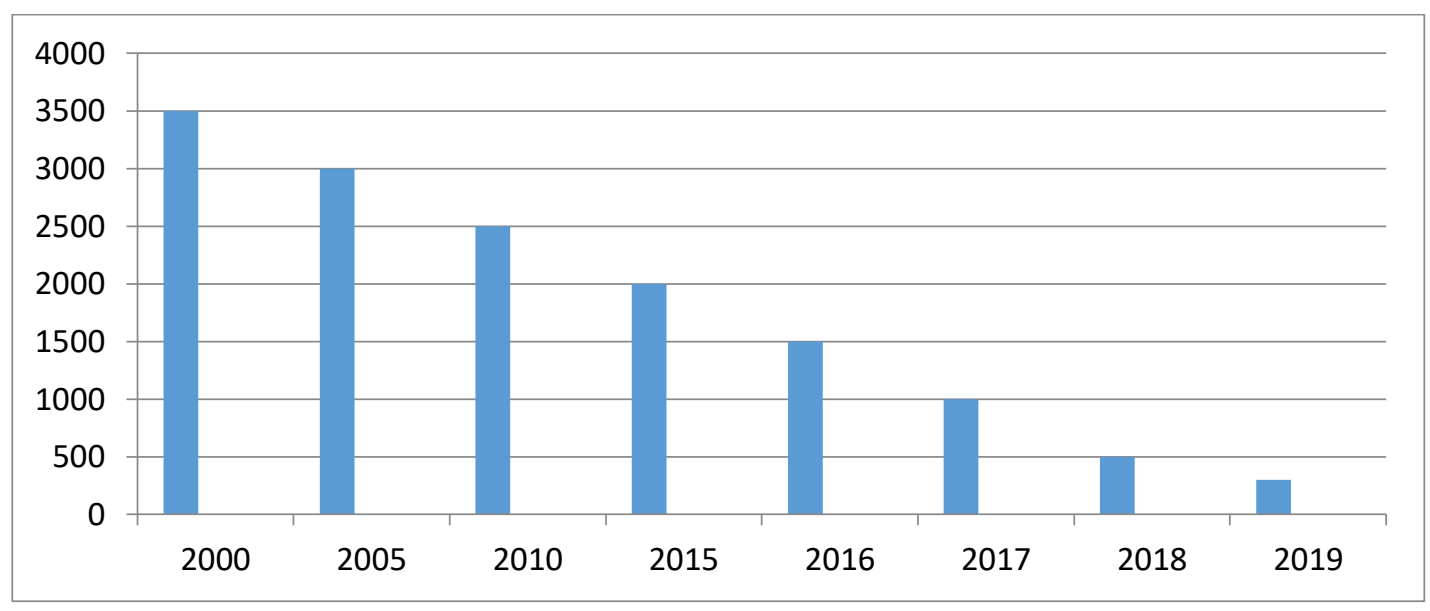

Figure1. Dynamics of joint-stock companies in the industry of Uzbekistan

As can be seen from the figure the volume of joint-stock companies have grown rapidly in numbers. If in 1991 the share of industrial GDP in the country was $9 \%$, in 2019 it would reach $37 \%$. Its share in exports is also growing. In particular, from year to year, the range of industrial products is increasing. 


\begin{tabular}{|c|c|c|c|c|c|c|}
\hline \multirow{4}{*}{ Impact Factor: } & ISRA (India) & $=3.117$ & SIS (USA) & $=0.912$ & ICV (Poland) & $=6.630$ \\
\hline & ISI (Dubai, UAE & $=0.829$ & РИНЦ (Russia & $=0.156$ & PIF (India) & $=1.940$ \\
\hline & GIF (Australia) & $=0.564$ & ESJI (KZ) & $=8.716$ & IBI (India) & $=4.260$ \\
\hline & JIF & $=1.500$ & SJIF (Morocce & $=5.667$ & OAJI (USA) & $=0.350$ \\
\hline
\end{tabular}

The growing diversification and clustering policies in our country have a great impact on these issues. It should be noted that on the basis of the localization program industrial products are increasing in all sectors of the industry, using the rich resources of our country.

Based on the industrial policy implemented by the Republic of Uzbekistan, the industrial sector is growing rapidly than other industries. Particularly, this is the 2017-2021 document adopted by the country's leadership. The current strategy for the five targeted areas is already being implemented. Based on this program, each industrial sector has been developing and promoting investment projects until 2021.



Figure 2. Dynamics of industrial production in Uzbekistan for 2011-2019.

For the development of the industry in the long term the quality and competitiveness of the products made up 40 billion sums. At this time, hundreds of percent of cotton produced in our country is being reproduced in our country. It should be stated that the economy of Uzbekistan has become an industrially developed state with full agrarian status. As we know, using the comparison method, you can identify the real situation in the economy. To understand the realities of industry development, it is necessary to compare its economy with other industries. The following table analyzes the development rates of industry in Uzbekistan with other sectors of economy. The analysis of the table shows that all the industries have grown rapidly in the recent period. The following situation can be observed when comparing the industrial sector with other sectors of the economy.

The development of industry in the conditions of market economy in Uzbekistan allows making the following conclusions:

- The industry should become a priority in the structure of the economy;

- Ensure structural transformation of the industry;

- Implement the industry with high technology and added value;

- Modernization, diversification in the industry, the development of a cluster policy;

- increase export capacity of industrial products;
- Increase the level of employment in industrial production, etc.

Corporate governance is a unique process not only in industrial production, but also in other sectors of the economy. From this point of view, the use of industry-wide corporate governance is a good way to do so. There is practically no experience of corporate governance in the industry of Uzbekistan. Therefore, it is important to study the mechanism of its introduction into the industry and increase the efficiency of corporate production. The key objective of introducing a corporate governance-based management mechanism in industry is to ensure that businesses benefit from a high level of enterprise balance.

The number of joint-stock companies in the industry decreased by 2049 , mainly due to the unreasonable increase in the number of private owners to develop property relations not only in industry, but also in other industries, lack of sustainability of enterprises, even lack of sufficient funds for dividends, thirdly, the low level of authorized funds of joint-stock companies, the outdated management methods and others. By 2017 this situation has changed dramatically. The charter capital of the jointstock companies was set at $\$ 400,000$. The action strategy program on socio-economic development of the country for 2017-2021 sets out the introduction of 


\begin{tabular}{|c|c|c|c|c|c|c|}
\hline \multirow{4}{*}{ Impact Factor: } & ISRA (India) & $=3.117$ & SIS (USA) & $=0.912$ & ICV (Poland) & $=6.630$ \\
\hline & ISI (Dubai, UAI & $=0.829$ & РИНЦ (Russia & $=0.156$ & PIF (India) & $=1.940$ \\
\hline & GIF (Australia) & $=0.564$ & ESJI (KZ) & $=8.716$ & IBI (India) & $=4.260$ \\
\hline & JIF & $=1.500$ & SJIF (Morocco & $=5.667$ & OAJI (USA) & $=0.350$ \\
\hline
\end{tabular}

corporate governance in improving the management of the economy and its enterprises [9].

The main task of managers in industrial enterprises is to establish the corporate governance system in market economy under the most efficient management principles of the joint-stock company's activity. Without taking into account the general principles of introduction of corporate production, the activity of industrial enterprises cannot be effectively organized. At the same time, the main purpose of corporate production should be to increase the efficiency of capital investments by investors and shareholders. In this regard, it is important to consider:

- Strengthening the benefits of corporate production, based on the interests of the shareholders;

- Same attitude towards all shareholders in corporate production;

- Ensuring compliance with the rights, rules and norms of shareholders listed in the corporate production system and the corporate code;
- Providing information on major shareholders for the development of corporate production.

Creation and regulation of a number of mechanisms for the growth of private industrial enterprises, especially large joint-stock companies, in the economy. Organization and development of organizational and economic mechanisms here is urgent because more workplaces are created, the tax code is considered to meet modern requirements, system of optimal pricing is created, effective management of savings.

Generally, two types of mechanism is important for the corporate development. From this point of view, organizational and economic mechanisms will be discussed separately. These organizational and economic mechanisms are important in corporate production, and their effective action is interconnected. The organizational mechanism of corporate production can be expressed as following Figure 3:

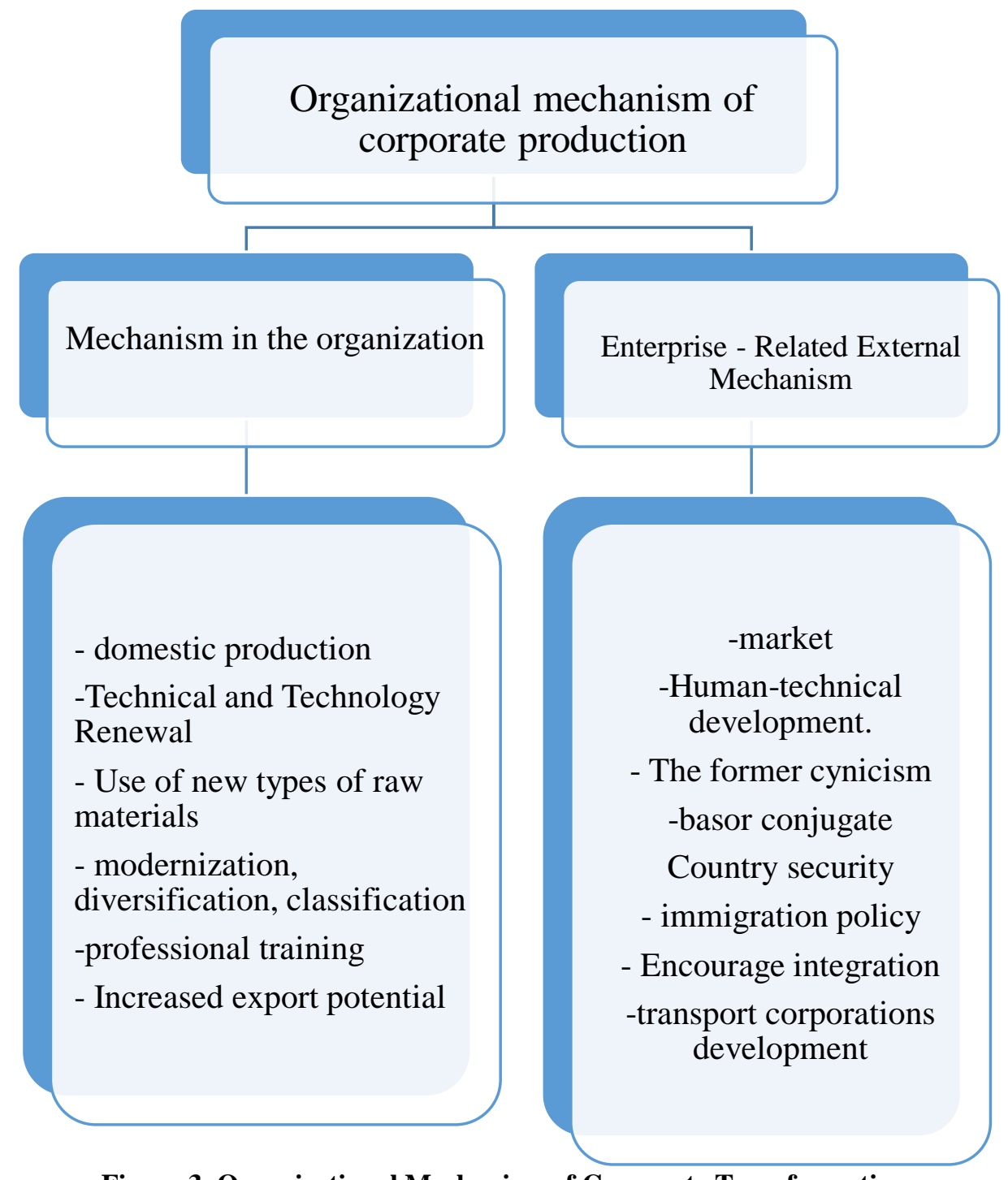

Figure 3. Organizational Mechanism of Corporate Transformation. 


\begin{tabular}{|c|c|c|c|c|c|c|}
\hline \multirow{4}{*}{ Impact Factor: } & ISRA (India) & $=3.117$ & SIS (USA) & $=0.912$ & ICV (Poland) & $=6.630$ \\
\hline & ISI (Dubai, UAI & $=0.829$ & РИНЦ (Russia & $=0.156$ & PIF (India) & $=1.940$ \\
\hline & GIF (Australia) & $=0.564$ & ESJI (KZ) & $=8.716$ & IBI (India) & $=4.260$ \\
\hline & JIF & $=1.500$ & SJIF (Morocco & $=5.667$ & OAJI (USA) & $=0.350$ \\
\hline
\end{tabular}

Achieving stability enhancing its profitability and positioning corporate productivity is largely reflected in the well-being of the economic mechanism of economic integration. As of 23 September 2016, the number of joint-stock companies operating in our country was 675 , the volume of issued securities amounted to 29,759.6 billion sums, according to the Central Securities Depository, as of September 14, 2016, 616 joint-stock companies (including 25 banks and 9 insurance companies), and the total amount of shares issued by them amounted to 46.75 trln. ( 8,77 trillion sums issued by the banks). The total number of ordinary and preferred shares in the circulation is $4.33 \mathrm{trln}$. is formed.

\section{Discussion}

The largest number of joint-stock companies is Uzpakhtasanoateksport (117 joint-stock companies, 1,86 trillion sums), Uzbekneftegaz (16,00 trillion sums), Uzbekenergo (41, 9.25 trillion sums) and Uzdonmahsulot (joint stock companies, 690.80 billion sums). At the same time, the authorized capital of the bank amounted to 232.78 billion sums, 43 commercial complexes and markets, operating in the form of jointstock company.

As of 09.12.2016 number of joint-stock companies and securities issued by the regions. Total Converted to Million Yuan Total relative percent

1. Korakalpakistan. 223.371 .30 .2

2. Andijan 436.5662 .92 .2

3. Bukhara 385.8124 .10 .4

4. Jizzakh 182.7307 .61 .0

5. Kashkadarya 477.1181 .50 .6

6. Navoi 223.3834 .42 .8

7. Namangan 294.4151 .80 .5
8. Samarkand 324.890 .90 .3

9. Surkhandarya 233.554 .40 .2

10. Syrdarya 172.6173 .20 .6

11. City of Tashkent 507.61109 .13 .7

12. Ferghana 467.0443 .11 .5

13. Khorezm 294.479 .90 .3

14. Tashkent City 24437.025540 .985 .6

Total 660100.029825 .0100 .0

Most joint-stock companies are located in the Tashkent region (228 joint stock companies or $37.01 \%$, with 42,39 trillion sums or $90.66 \%$ of shares issued), and at least in Syrdarya region (16 joint stock companies or $2.59 \%$ billion sums or $0.36 \%$ ). According to the data given above there are 244 joint-stock companies operating in Tashkent city, with a maximum of 24,500 (37.6 percent of total assets) and 25,540.9 billion sums (85.6 percent of total assets). At least 17 joint-stock companies operate in Syrdarya region. Surkhandarya region has the lowest share of securities issued by joint-stock companies, which amounts to 54.4 billion sums $(0.2 \%$ of the total). This indicator is 469.5 times lower than in Tashkent. The share of each region in total volume of share-based companies and the total number of issued securities can be clearly seen in the figure below.

The analysis of data presented in Figure 1.2.3 shows that the share of securities issued by joint-stock companies in Uzbekistan among all regions of the country is considerably higher than the number of joint-stock companies. In other regions, this figure is relatively low. It would be expedient to pay attention to the territorial location of joint-stock companies to ensure further socio-economic development of all regions and regions of the Republic.

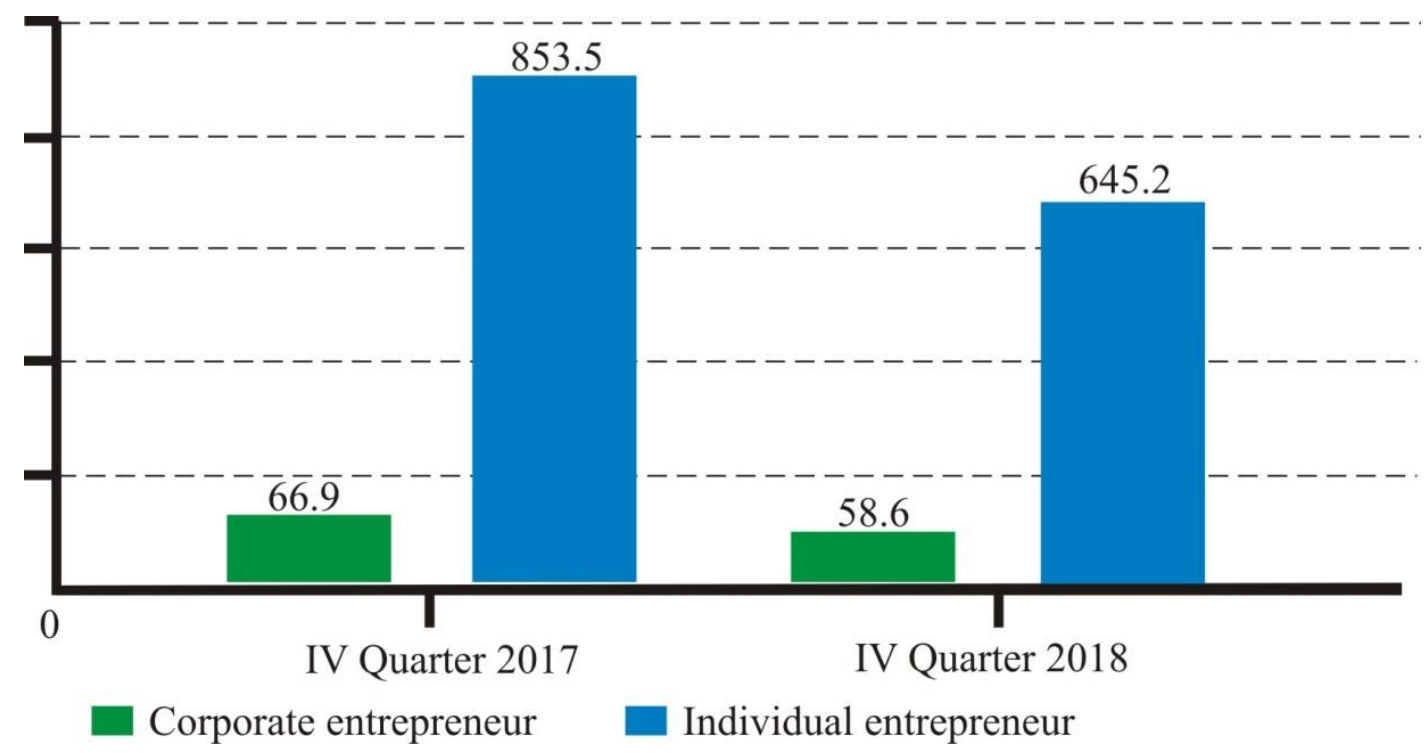

Figure 4. Comparative chart of the number of securities accounts, served by investment intermediaries (thousand pieces) 


\begin{tabular}{|c|c|c|c|c|c|c|}
\hline \multirow{4}{*}{ Impact Factor: } & ISRA (India) & $=3.117$ & SIS (USA) & $=0.912$ & ICV (Poland) & $=6.630$ \\
\hline & ISI (Dubai, UAE & $=0.829$ & РИНЦ (Russia & $=0.156$ & PIF (India) & $=1.940$ \\
\hline & GIF (Australia) & $=0.564$ & ESJI (KZ) & $=8.716$ & IBI (India) & $=4.260$ \\
\hline & JIF & $=1.500$ & SJIF (Morocce & $=5.667$ & OAJI (USA) & $=0.350$ \\
\hline
\end{tabular}

The Central Securities Depository registers the rights to securities owned by 39 investment intermediaries and its clients by keeping their accounts. The number of depositors, clients of investment intermediaries having non-zero balances on the deposit account as of 01/01/2019 is 712.8 thousands of accounts, incl. 58.6 thousand or $8.2 \%$ of legal entities and 654.2 thousand or $91.8 \%$ individuals. Compared to the same period last year, the number of accounts the depot decreased by $22.5 \%$.
(As of 01.01.2018, there are 920.3 thousand depositors, including Comparative chart of the number of securities accounts, served by investment intermediaries (nominee holders)(thousand pieces) 66.9 thousand, or $7.3 \%$ of legal entities and 853.5 thousand or $92.7 \%$ of individuals, of the total number of depositors.)The total amount of securities accounted for by investment intermediaries on $01 / 01 / 2019$, at nominal value amounted to 4836.8 billion sums, or 2,366.9 billion pieces of securities.

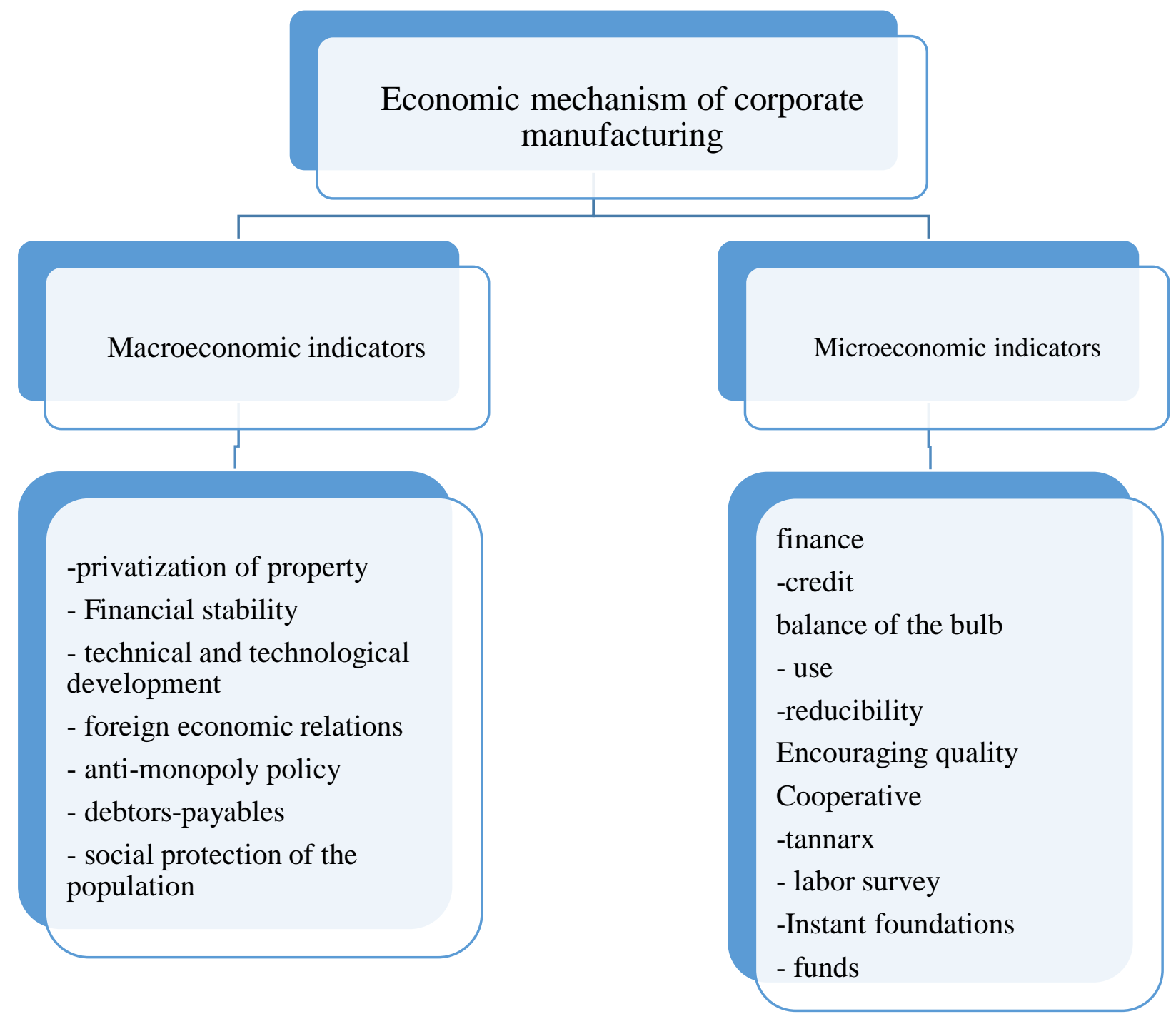

Figure 5. Model of economic mechanism for corporate governance management.

Analysis shows that economic mechanism of corporate governance management designed as above figure 5. It is described that corporate macroeconomic performance can be even wider, but in terms of sustainability and efficiency the most important is the stable economic relations. The mechanism of efficiency in corporate production is calculated by some of the most important coefficients. In practice, the following coefficients can be used to identify the ways to ensure financial sustainability of industrial enterprises:

\section{Solvency coefficient of the enterprise.}

$\mathrm{Kl}=(\mathrm{Cf} / \mathrm{kg}) * 100$ in this, (1)

$\mathrm{K} 1$ - coefficient of solvency;

Sf - net profit;

$\mathrm{Kg}$ - creditor debt. 


\begin{tabular}{|c|c|c|c|c|c|c|}
\hline \multirow{4}{*}{ Impact Factor: } & ISRA (India) & $=3.117$ & SIS (USA) & $=0.912$ & ICV (Poland) & $=6.630$ \\
\hline & ISI (Dubai, UAE & $=0.829$ & РИНЦ (Russia & $=0.156$ & PIF (India) & $=1.940$ \\
\hline & GIF (Australia) & $=0.564$ & ESJI (KZ) & $=8.716$ & IBI (India) & $=4.260$ \\
\hline & JIF & $=1.500$ & SJIF (Morocce & $=5.667$ & OAJI (USA) & $=0.350$ \\
\hline
\end{tabular}

The smaller the size of the debtor's debt, the higher its effectiveness.

2. Financial stability coefficient.

$K 2=(C f / A m) * 100$ in this case, $(2)$

$\mathrm{K} 1$ - stability coefficient;

Sf - net profit;

Am - turnover funds.

3. Absolute liquidity ratio.

$\mathrm{K} 3=(\mathrm{Cf} / \mathrm{Kb}) * 100$ in this, (3)

$\mathrm{K} 3$ - liquidity ratio;

Sf - net profit;

$\mathrm{Kb}$ - working capital.

4. Depreciation of fixed assets.

$\mathrm{Ke}=Q e-Q y a *(U e * T e) /$ Uya $*$ Tya in this, (4)

$\mathrm{Ke}$ - value of fixed assets;

Qe, Kya - the original value of old and new equipment;

Ue, Uya - annual productivity of old and new equipment;

Te, Tya - outdated and expiration date of new equipment.

5. Renewal coefficient.

$K y a=(F d / Q y) * 100$ in this case, (5)

Kya - refinement coefficient;

$\mathrm{Fd}$ - the value of the periodic fixed assets;

Qy - the end of the year.

6. The cost of liquidation of funds.

$K T=K t / K d$ in this case, (6)

$\mathrm{CT}$ - cost of liquidation of funds;

$\mathrm{Kt}$ - value of liquidated funds;

$\mathrm{Kd}$ - is the value of funds at the beginning of the periodicity.

7. Production efficiency.

$R k=(F / A f . q 1+A f . q 2) * 100$ In this case, (7)

$\mathrm{Rk}$ - production efficiency;

Af.q-value of fixed assets;

Af.q2 - the value of the working capital.

Based on the above formula, financial stability of the enterprise is determined.

One of the fundamentals of corporate governance is an effective organization of corporate productions. Taking this into account, from the governing body of corporate governance, the proper organization of the workforce of the bottoms managers, the increase in their useful business coefficients, and the efficient use of working hours have a great impact on the effectiveness of the corporate governance mechanism. The board of directors, which is one of the key aspects of the organization of its operations, has been given an important place in the supervisory board.

It is expedient to use the foreign experience of the board of directors in the business of Uzbekistan. However, it should be noted that although this issue has been going on in foreign countries for many years, there are still differences in this issue. However, there are sufficient legal and regulatory documents on this issue. For example, external members of the US Experts Board were simultaneously a member of other companies. Observers can often be professors and teachers of universities. However, members of the board of directors of one third to one-third of the members of the Supervisory Board. The advantages of supervisory boards with external members that exhibit industrial enterprises are that they can successfully evaluate the management of an industrial enterprise than a board member who has no work experience in the industry.

According to the law, there are no representatives of industrial companies in the German supervisory boards. Only members of the stockholders and members of the board of directors of the industrial enterprises are considered in the sectors.

It should be noted that there is little experience in industrial enterprises of our country. However, he adopted a number of decrees, laws and regulations on the activities of directors and supervisory boards. As for foreign experience in this regard, it is necessary to organize their activities based on directors and supervisory boards, their powers and responsibilities, taking into account the characteristics, principles and other aspects of their use in Uzbekistan [11].

The study of terminology of the evolution of the theory of corporate governance and the development of their concepts. These terminologies include Corporate Governance, Corporate Governance, Corporate Production System, Corporate Productivity, Corporate Culture. The study of the evolution of corporate governance is a theoretically significant one. Taking into account the broad definition of the concept of corporate governance, it was suggested that this problem would be promptly understood and it would be expedient to study the evolutionary development of these concepts in a timely manner.

\section{Conclusion}

In conclude, implementing corporate governance in industry development in Uzbekistan Central Depository of Uzbekistan visited Representatives of the information technology company "Mosaic" (USA). The main purpose of the cooperation is accounting services provided by the company and developed software for portfolio management papers. As well as the challenges facing the Central Depository of Uzbekistan in establishing interaction with the international central depositories "Euro clear", Clear stream. In March of this year, the Central Depository of Uzbekistan held meeting with representatives of the advisory mission of the Asian Development Bank, arrived in Uzbekistan to discuss issues of further development financial market of Uzbekistan and the preparation of technical specifications for diagnostic capital market research. Modern corporate governance system and approaches are now being tested in some joint-stock companies. The most effective models and programs will be implemented by developing sectors in Uzbekistan. 


\begin{tabular}{|c|c|c|c|c|c|c|}
\hline \multirow{4}{*}{ Impact Factor: } & ISRA (India) & $=3.117$ & SIS (USA) & $=0.912$ & ICV (Poland) & $=6.630$ \\
\hline & ISI (Dubai, UAE & $=0.829$ & РИНЦ (Russia & $=0.156$ & PIF (India) & $=1.940$ \\
\hline & GIF (Australia) & $=0.564$ & ESJI (KZ) & $=8.716$ & IBI (India) & $=4.260$ \\
\hline & JIF & $=1.500$ & SJIF (Morocce & $=5.667$ & OAJI (USA) & $=0.350$ \\
\hline
\end{tabular}

Effective managing employees and other personals are only the best providers of company efficiency and productivity. By the sample of the developed companies and multinational corporations is the predominant example for us to sustainable economic growth in all sectors of the economy in Uzbekistan.

\section{References:}

1. Masyuktin, S. A. (2003). Corporate governance: experience and problem. (p.33). Moscow: Fina.

2. Karnauxov, S. (2004). Effektivnost korporativnyx structure. Risk-Moscow, 2004. № 1-2, p. 4.

3. Kukura, S. P. (2004). Theory of corporate governance. (p.478). Moscow: ZAO, Publishing House. Economics.

4. (2008). Corporate management. Tutorial. Under the general editorship of I.I. Mazur and V.D.Shapiro (Eds.). Publ. Omega-I.

5. Zaynutdinov, S. N., \& Raximova, D. N. (2007). Corporate Bosharuv Asoslari. (p.48). Tashkent: Academy.

6. Amidulin, M. (2008). Financial mechanisms of corporate governance. (p.204). Tashkent: Molia.
7. Berkinov, B. B. (2005). Corporate structures (basis of creation and management). (p.132). Tashkent: Publishing House Nat, b-ki Uzbekistan.

8. Rasulov, N. M. (2011). Corporate Bosharuv is an investment samardorligi kafolati. (pp.16-17). Tashkent: TDIU.

9. (2017). Presidential Decree. 2017-2021 is a strategy program for socio-economic development of the country. Tashkent.

10. Hraborova, I. A. (2000). Corporate governance: Integration. (p.64). Moscow.

11. Khoshimov, A. A. (2003). Prospects for development of corporate governance structures. (p.29). Tashkent: Fan. 